University of Nebraska - Lincoln

DigitalCommons@University of Nebraska - Lincoln

Faculty Publications: Political Science

Political Science, Department of

January 2004

\title{
White Racial Attitudes and Support for the Mississippi State Flag
}

Byron D'Andra Orey

University of Nebraska-Lincoln, borey2@unl.edu

Follow this and additional works at: https://digitalcommons.unl.edu/poliscifacpub

Part of the Political Science Commons

Orey, Byron D’Andra, "White Racial Attitudes and Support for the Mississippi State Flag" (2004). Faculty Publications: Political Science. 3.

https://digitalcommons.unl.edu/poliscifacpub/3

This Article is brought to you for free and open access by the Political Science, Department of at DigitalCommons@University of Nebraska - Lincoln. It has been accepted for inclusion in Faculty Publications: Political Science by an authorized administrator of DigitalCommons@University of Nebraska - Lincoln. 


\section{RESEARCH NOTE}

\section{White Racial Attitudes and Support for the Mississippi State Flag*}

\author{
BYRON D'ANDRA OREY'
}

University of Nebraska at Lincoln

\begin{abstract}
In recent years, there has been a dearth of literature documenting a relationship between old-fashioned racism and the vote for a racially conservative candidate or White opposition to various racial policies. In fact, a number of scholars have argued that a new racism has supplanted the old-fashioned racism. Analysis of a survey of college students in the state of Mississippi reveals that old-fashioned racism provides the strongest explanation of White support for the Mississippi state flag. These findings are startling given the educational levels of the respondents.
\end{abstract}

Keywords: racism; Confederate flag; Rebel flag; White racial attitudes

* Published in AMERICAN POLITICS RESEARCH, Vol. 32 No. 1, January 2004, 102-116. Copyright (C) 2004 Sage Publications. Used by permission. DOI: 10.1177/1532673X03255169

+ Author's Note: An earlier version of this paper was presented at the 2001 Southern Political Science Association meeting in Atlanta, GA. The author thanks John Comer, Susan Howell, Harvey Palmer, Khalilah Brown-Dean, Robert Albritton, and Ken McGraw (project director for PsychExps), as well as the anonymous peer reviewers for their helpful comments and suggestions.
$\mathbf{O}$ n April 17, 2001, Mississippi held a referendum for the purpose of choosing a state flag. During the referendum, voters were given the option of retaining their 107-year old state flag with the Confederate insignia of 13 white stars on a blue $X$ over a red field in the top insider corner (proposition A on the ballot), or of replacing it with a new flag possessing concentric circles of 20 white stars on a blue square (proposition B on the ballot), representing Mississippi as the 20th state accepted to the union. The proposed new flag failed by a wide $65 \%$ to $35 \%$. The research question posed here is, What explains support for the Confederate flag (also known as the Rebel flag)?

The 2001 referendum was made possible after it was discovered that Mississippi did not have an official state flag. In 1993 the National Association for the Advancement of Colored People (NAACP) filed a lawsuit to remove the Mississippi state flag. According to the organization the flag serves as a "vestige of slavery." On review of the case, the Mississippi Supreme Court revealed that Mississippi had not possessed an official state flag since 1906.Agovernor-appointed bipartisan commission decided that a state flag referendum would occur on April 17, 2001.

This research builds on the work of Clark (1997) and Reingold and Wike (1998) in their assessment of White racial attitudes toward the Georgia state flag. Similar to Mississippi, Georgia's state flag also possessed the Confederate battle emblem. Clark examines the support of political campaign contributors from the state of Georgia and their support for the Georgia state flag. Due to data limitations, Clark acknowledges that the "survey contained only one item pertaining to racial attitudes" (p. 486). Despite the crude measurement for racial attitudes, however, the author still finds it to be the strongest explanation of White support for the Georgia state flag. Reingold and Wike (1998) find racial resentment (also known as symbolic racism) to far exceed the impact of southern identity when explaining support for the Georgia state flag. These findings challenge the notion that White support for the flag is a function of their southern heritage. 
In addition to Mississippi and Georgia, the Confederate flag has also proved to be controversial in the state of South Carolina. In 1962, members of the South Carolina legislature placed a Confederate flag on top of the state capitol (Woliver, Ledford, \& Dolan, 2001). Supporters of the flag in South Carolina argued that the flag represented their history and not hatred. In July of 2000, a compromise was made and the flag was removed from atop the state capitol and placed in a new location on the capitol grounds. At current, the case of Mississippi differs from both Georgia and South Carolina because it is the only state that has conducted a statewide referendum.

The study of racial attitudes toward the Mississippi state flag differs from previous studies that examine racial attitudes toward such racial policy issues as affirmative action, in that the flag referendum was symbolic and did not result in a tangible policy output. Like flag supporters in South Carolina, advocates of the Mississippi state flag argue that the flag represents their heritage. On the other hand, those who oppose the flag complain that the flag stands as a symbol of hatred. The division generally breaks down along racial lines. On average, Whites say that the flag represents heritage, whereas many African Americans see the flag as offensive, serving as a symbol of racial hatred and a reminder of slavery. According to a statewide, pre-referendum poll conducted by The Clarion Ledger newspaper, approximately $76 \%$ of Whites indicated that "the Confederate battle symbol is a part of the state's proud history and traditions, and therefore should not be removed from the flag" (The Clarion Ledger, 2001, p. 3). ${ }^{1}$ To the contrary, approximately $69 \%$ of African Americans responded that "the Confederate battle symbol is offensive and divisive to some groups and should be removed" (The Clarion Ledger, 2001, p. 3). Given the contentious debate surrounding the Mississippi state flag and the accusations of racism associated with the flag, the current research provides a systematic analysis to examine White support for the Mississippi state flag.

\section{UNDERSTANDING WHITE RACIAL ATTITUDES}

\section{OLD FASHIONED RACISM}

According to Webster's Encyclopedic Unabridged Dictionary, racism is "a belief that human races have distinctive characteristics that determine their respective cultures, usually involving the idea that one's own race is superior and has the right to rule others." In this vein, the old-fashioned racism that existed during the days of Jim Crow placed focus on White supremacy (i.e., biological superiority).

In recent years, scholars have argued that a new racism has supplanted the old-fashioned racist belief that African Americans are biologically inferior to Whites. Gilens (1995; see also Virtaneen \& Huddy, 1998) conducted a factor analysis using the 1986 National Election Studies (NES) data and found two distinct dimensions that correspond to separate types of racism, the old-fashioned racism and the new racism. He reports that the new racism trumps the old-fashioned racism in explaining opposition to welfare spending. Howell (1994), in her research examining determinants of White support for David Duke, finds support for the new racism but finds no support for the old-fashioned racism. In previous studies, the following items have been employed to operationalize old-fashioned racism: (a) the races are different due to a divine plan, and (b) Blacks come from a less able race (in the 1986 NES); (c) there should be laws against marriages between Blacks and Whites, and (d) White people have a right to keep Blacks out of their neighborhoods (in the 1994 General Social Survey [GSS]).

\section{RACIAL RESENTMENT}

Symbolic racism (same as racial resentment), a concept originally articulated by Sears and Kinder (1971), posits that White racial attitudes are no longer shaped by biological racism, the notion that Blacks are an inherently inferior race to Whites. These authors note that individuals who possess symbolic racial attitudes believe "that blacks violate such traditional American values as individu- 
alism and self-reliance, the work ethic, obedience, and discipline" (Kinder \& Sears, 1981, p. 416). According to Sears (1988), symbolic racism is composed of an anti-Black affect and traditional American moral values.

One of the principal architects of the symbolic racism concept, Kinder (see Kinder \& Sanders, 1996, Appendix A), has reconsidered his decision to use symbolic racism to describe these attitudes and has opted (along with Sanders) to use racial resentment as a description for such attitudes (see also Orey, 2001). The research at hand follows the lead of Kinder and Sanders (1996) and employs racial resentment as the label for the racial attitudes described in this paper. ${ }^{2}$

Kinder and Sears (1981) note that, despite the growth in research examining conceptualizations of racial prejudice, there has been a dearth of empirical confrontations between competing theories (for an exception see Bobo, 2000). Along these lines, the current research examines the impact of both old-fashioned racism and racial resentment to explore White support for the Mississippi state flag. Mississippi serves as an excellent case to test such racial attitudes because of the state's longstanding history of massive resistance to civil rights. Indeed, it was not until 1995 that the Mississippi state legislature ratified the 13th Amendment.

\section{DATA AND METHOD}

The data are derived from a self-administered survey of college students. ${ }^{3}$ This survey consists of 847 respondents from eight universities, located in different regions throughout the state of Mississippi. ${ }^{4}$ The current analysis on these data, however, is confined to White respondents, thus reducing the total sample size to 542 . The survey was administered from April 9, 2001 to April 16, 2001, the week before the referendum, to students taking introductory social science courses. We suggest that the use of college students in this sample actually helps to buttress our argument. In particular, we can infer that if racial attitudes are found to be predictive among college educated students, those individuals with less education will be equally, if not more likely, to have racial attitudes undergirding their support for the flag. In short, our results are expected to underestimate the findings that would be expected among the general public.

Generalized Least Squares (GLS) is employed to examine the data. GLS is adopted because of a need to weight the data based on the university and enrollment size of the various colleges and universities. Said differently, because the enrollment size of each of the universities is different and the number of respondents from each university varies, the data are weighted based on the following proportion: $\left(N_{\mathrm{i}} / N\right) /\left(M_{\mathrm{i}} / M\right)$, where $N$ is the total number of students across all universities surveyed, $N_{\mathrm{i}}$ is the number of students at university $i, M$ is the total number of respondents across all universities surveyed, and $M_{\mathrm{i}}$ is the number of respondents at university $i$.

\section{DEPENDENT VARIABLE}

The dependent variable is a continuous variable tapping the strength of support for the Confederate flag. Initially, respondents were asked to choose between the proposed new flag and the current state flag (the Confederate flag). Those who chose the newly proposed flag were given a score of 0 . Those who chose the current state flag were then asked to respond to the following question: "On a scale from 0 to 10, How strongly do you feel about your choice?" A value of 10 represents the strongest level of support for the Confederate flag and a value of 0 represents a lack of support for the Confederate flag.

\section{INDEPENDENT VARIABLES}

The two key independent variables in this analysis are old-fashioned racism and racial resentment. Both of the scales are constructed using Likert-type items (these items do not include the hedging response of neither agree nor disagree). The old-fashioned racism scale is operationalized with three Likert-type items: God 
made the races different as part of His divine plan, Blacks come from a less able race, and disapproval of marriage between Blacks and Whites. The items were found to load fairly well on one factor. An additive scale of the three items, however, produces a somewhat low alpha coefficient of $.36 .{ }^{5}$

The racial resentment scale is operationalized with four Likert-type items: Blacks have gotten less than they deserve; Blacks should overcome prejudice without special favors; If Blacks try hard they can be just as well off as Whites; and Generations of slavery and discrimination prevent Blacks from getting ahead. Similar to the items adopted to create the old-fashioned racism scale, the items employed to create the racial resentment scale, all load well on one factor. These four items were combined to create an additive scale. The alpha coefficient is .77. The question wording for all of these items is presented in Table $1 .^{6}$

\section{TABLE 1}

Frequency Distributions for Strength Toward the Flag

\begin{tabular}{ccc} 
Strength toward the flag & Frequency & $\%$ \\
\hline 0.00 & 166 & 27.95 \\
0.10 & 5 & 0.84 \\
0.20 & 9 & 1.52 \\
0.30 & 7 & 1.18 \\
0.40 & 12 & 2.02 \\
0.50 & 26 & 4.38 \\
0.60 & 33 & 5.56 \\
0.70 & 40 & 6.73 \\
0.80 & 54 & 9.09 \\
0.90 & 37 & 6.23 \\
1.00 & 205 & 34.51 \\
\hline
\end{tabular}

In an effort to ensure that the model is fully specified, the analysis provides controls for partisanship (Knuckey \& Orey, 2000), ${ }^{7}$ individualism (Gilens, 1995), gender (Howell \& Pelinka, 1994), age (Clark, 1997; Brill \& Grant, 1995), and ideology (Sears, Van Laar, Carrillo, \& Kosterman, 1997). Partisanship is measured by self-identification on a 7-point scale where Republican takes on a value of 1 . Similarly, ideology is measured so that conservatism takes on a value of 1 . Individualism is measured based on a single question consisting of a 10-point scale running from "The government in Washington should see to it that every person has a job and a good standard of living" at one end (0), to "The government should just let each person get ahead on their own" at the opposite end (1) (e.g., Gilens, 1995, p. 1003). Gender takes on a value of 1 for males and 0 for females. Age is simply the respondent's age.

For the purpose of clarifying the interpretation of the unstandardized regression coefficients in the regression analysis, all of the variables except age have been transformed to range from 0 to 1 .

\section{WHITE RACIAL ATTITUDES AND THE REBEL FLAG}

On a scale ranging from 0 to 1 , the average strength of White support for the Rebel flag is approximately .59. Among the 594 respondents, Table 1 indicates that 166 (or 27.95\%) disapproved of the old flag (i.e., rated the flag at 0 ). In addition, Table 1 also reveals that approximately $35 \%$ of the respondents rated the flag at the maximum level of 1 . Hence, there exists a bimodal distribution, indicating that people feel very strongly in their opinions toward the flag.

Question wording for the old-fashioned racism and racial resentment items are included in Table 2.8 According to Table 2, roughly $44 \%$ of the respondents believed the differences that exist between Blacks and Whites are attributed to God's divine plan. Only about $6 \%$, however, believe that Blacks are not as well off as Whites because Blacks come from a less able race. About half of 
the respondents disapproved of marriages between Blacks and Whites. In addition, as it relates to the racial resentment variable, approximately $75 \%$ of the respondents disagree with the notion that in recent years, Blacks have gotten less than they deserve. Likewise, another $75 \%$ agree that if other ethnic groups have been able to pull themselves up by their bootstraps, Blacks should do the same. Roughly, $65 \%$ of Whites believe that the differences between Whites and Blacks are simply attributed to Blacks' not trying hard enough. Lastly, about $57 \%$ of Whites disagree with the notion that slavery has played a role in the persistent levels of poverty in the Black community.

\section{TABLE 2}

\section{Question Wording}

\section{Racial Resentment}

Now I am going to read several statements. After each one, I would like you to tell me whether you agree strongly, agree somewhat, disagree somewhat, or disagree strongly.

Receive less. Over the last few years, Blacks have gotten less than they deserve. (Disagree)

$\begin{array}{lr}\text { Agree strongly } & 2.9 \\ \text { Agree somewhat } & 21.4 \\ \text { Disagree somewhat } & 42.5 \\ \text { Disagree strongly } & 33.0\end{array}$

Minorities overcame prejudice. Irish, Italians, Jewish, and other minorities overcame prejudice and worked their way up. Blacks should do the same without any special favors. (Agree)

$\begin{array}{lr}\text { Agree strongly } & 32.6 \\ \text { Agree somewhat } & 42.2 \\ \text { Disagree somewhat } & 25.7 \\ \text { Disagree strongly } & 3.2\end{array}$

In past studies, we have asked people why they think White people seem to get more of the good things in life in America such as better jobs and more money than Black people do. These are some of the reasons given by both Blacks and Whites. Please tell me whether you agree or disagree with each reason.

Try harder. It's really just a matter of some people not trying hard enough. If Blacks would only try harder they could be just as well off as Whites. (Agree)

$\begin{array}{lr}\text { Agree strongly } & 20.5 \\ \text { Agree somewhat } & 45.4 \\ \text { Disagree somewhat } & 25.9 \\ \text { Disagree strongly } & 8.2\end{array}$

Slavery created conditions. Generations of slavery and discrimination have created conditions that make it difficult for Blacks to work their way out of the lower class. (Disagree)

$\begin{array}{lr}\text { Agree strongly } & 8.0 \\ \text { Agree somewhat } & 35.1 \\ \text { Disagree somewhat } & 28.7 \\ \text { Disagree strongly } & 28.2\end{array}$

\section{Old Fashioned Racism}

The differences are brought about by God; God made the races different as part of His Divine Plan. (Agree)

$\begin{array}{ll}\text { Agree strongly } & 20.8 \\ \text { Agree somewhat } & 23.5 \\ \text { Disagree somewhat } & 20.0 \\ \text { Disagree strongly } & 35.8\end{array}$

Blacks come from a less able race and this explains why Blacks are not as well off as Whites in America.

$\begin{array}{lr}\text { Agree strongly } & .7 \\ \text { Agree somewhat } & 5.1 \\ \text { Disagree somewhat } & 20.6 \\ \text { Disagree strongly } & 73.6\end{array}$

Do you approve or disapprove of marriage between Blacks and Whites? $\begin{array}{ll}\text { Approve } & 50.2 \\ \text { Disapprove } & 49.5\end{array}$

NOTE: Figures may not total $100 \%$ owing to rounding errors. 
According to the frequency distributions reported in Table 3, only about $7 \%$ of Whites score above .5 on the 0 to 1 old-fashioned racism scale. To the contrary, Table 4 reports that more than $50 \%$ of Whites score above .5 on the 0 to 1 resentment scale. Jackman (1996; see also Jackman \& Muha, 1984) argues that educated Whites often render socially desirable responses on issues pertaining to race. Hence, the actual number of respondents expressing old-fashioned racist attitudes is generally attenuated.

\section{TABLE 3}

\section{Frequency Distributions for Old-Fashioned Racism Scores}

\begin{tabular}{rcr} 
Scores & Frequency & $\%$ \\
\hline .00 & 120 & 21.13 \\
.20 & 107 & 18.84 \\
.40 & 106 & 18.66 \\
.50 & 195 & 34.33 \\
.60 & 33 & 5.81 \\
.80 & 6 & 1.06 \\
1.00 & 1 & 0.18 \\
Totals & 568 & 100.00 \\
\hline
\end{tabular}

The findings of the regression model are reported in Table 5 and Table $6 .{ }^{9}$ The findings in Table 5 reveal that those individuals who possess old-fashioned racist attitudes provide the strongest support for the Mississippi state flag. These findings are startling given the fact that our sample consists of college students. The expectation was that the use of college students would attenuate the significance of racial attitudes in explaining White support for the flag. That is clearly not the case here. Second, in recent years, there has been a dearth of findings supporting the old-fashioned racism hypothesis in the extant literature.
TABLE 4

Frequency Distributions for Racial Resentment Scores

\begin{tabular}{ccc} 
Scores & Frequency & $\%$ \\
\hline .00 & 3 & .53 \\
.10 & 5 & .88 \\
.20 & 12 & 2.11 \\
.30 & 19 & 3.33 \\
.40 & 23 & 4.04 \\
.50 & 206 & 36.14 \\
.60 & 66 & 11.58 \\
.70 & 77 & 13.51 \\
.80 & 65 & 11.40 \\
.90 & 54 & 9.47 \\
1.00 & 40 & 7.02 \\
Totals & 570 & 100.0 \\
\hline
\end{tabular}

According to Table 5, a full 1-unit change in racial views-that is, a change from scoring a 0 to scoring a 1 on the old-fashioned racism scale-is associated with a change of about two-thirds of the possible range (.67 to be exact) in support for the Confederate flag. The racial resentment variable is also strongly related to support for the flag. A 1-unit change in racial resentful attitudes-in other words, moving from a racial tolerant score of 0 to a racial resentful score of $1-$ is associated with a change of more than half of the possible range (.52 to be exact) in support for the Confederate flag. Based on these results and the standardized beta coefficients reported in Table 5, the magnitude of the old-fashioned racism coefficient is greater than the racial resentment coefficient. Moreover, racial attitudes (i.e., old-fashioned racism and racial resentment), serve as the strongest explanation, by far, of support for the Rebel flag. Other variables achieving statistical significance include both ideology and gender. That is, conservatives and women were more likely to support the flag, based on the signs of 
these coefficients. Initially, the results for the gender variable were somewhat surprising. However, these results are consistent with those reported in a pre-referendum survey suggesting that women were just as likely to support the flag, when compared with their male counterparts (The Clarion Ledger, 2001, p. 2).

\section{TABLE 6}

Model Explaining Support for the Confederate Flag in Mississippi With Individual Old-Fashioned Racism Components Modeled Separately (Whites Only)

\begin{tabular}{lcll} 
Independent Variable & \multicolumn{2}{c}{$b$} & $\beta$ \\
\hline God $^{\mathrm{a}}$ & $0.17^{* *}$ & $(0.04)$ & 0.16 \\
Less race $^{\mathrm{b}}$ & $0.40^{* *}$ & $(0.08)$ & 0.20 \\
Marriage $^{\mathrm{c}}$ & $0.14^{* *}$ & $(0.03)$ & 0.17 \\
Resentment & $0.53^{* *}$ & $(0.09)$ & 0.26 \\
Party identification & 0.05 & $(0.07)$ & 0.03 \\
Ideology & $.28^{* *}$ & $(0.09)$ & 0.13 \\
Individualism & -0.003 & $(0.009)$ & -0.008 \\
Gender & $-0.10^{* *}$ & $(0.03)$ & -0.10 \\
Age & 0.003 & $(0.004)$ & 0.003 \\
Constant & -0.10 & $(0.12)$ & \\
$N$ & 542 & & \\
Weighted adj. $R^{2}$ & 0.31 & & \\
\hline
\end{tabular}

NOTE: Robust standard errors are in parentheses. Components of old-

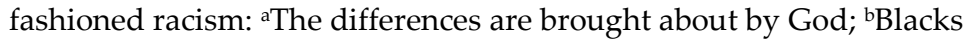
come from a less able race; and cdisapproval of marriage between Blacks and Whites.

${ }^{*} p<.05$. ${ }^{* *} p<.01$.

Finally, because of the low alpha score achieved by the oldfashioned racism variable, the components were analyzed separately. Table 6 indicates that all of the components of the oldfashioned racism variable are statistically significant. The greatest impact, based on the standardized beta coefficients, comes from those Whites who believe that Blacks come from a less able race. In sum, even when disaggregated, the components that make up the Old-Fashioned Racism Scale perform strongly in explaining White support for the Confederate flag.

The findings reported here both support and run counter to those reported in the extant literature. For example, the research here finds that the old-fashioned racism variable provides a stronger explanation of support for the flag when compared with racial resentment. However, Howell (1994), in her analysis of White support for David Duke, reports that racial resentment trumps old-fashioned racism. In fact, she finds no support for the old-fashioned racism variable as a predictor of the vote for Duke. On the other hand, the findings here support those of Clark (1997) and Reingold and Wike (1998). Like these authors, this analysis finds strong support for White racial attitudes (in this case both old-fashioned racism and racial resentment) and support for the Confederate flag. However, as stated above, the case of Mississippi differs from that of Georgia because it is the first state to conduct a referendum as a remedy for the flag conflict. The analysis here also differs from previous analyses in that it provides a control for both the old-fashioned racism and the new racism (i.e., racial resentment).

\section{CONCLUSION}

Once the bastion of racial oppression in the United States, Mississippi serves as an excellent case study for examining contemporary racial attitudes in the deep South. The April flag referendum allows us to examine whether support for the Confederate flag is a function of racial attitudes, while at the same time considering other related variables.

Racism proves to be strongly related to the intensity of support for the Confederate flag in Mississippi. Indeed, the coefficients for both of the racial attitude variables have at least twice the impact of any other variable in the model. Surprisingly, old- 
fashioned racism has a greater magnitude than racial resentment in explaining support for the Confederate flag. These findings are surprising for a couple of reasons. First, given that the sample consists of college students, it was expected that the results would be attenuated because of socially desirable responses to the racial attitude questions, especially the old-fashioned racism questions. Secondly, in recent years there has been a dearth of research finding support for old-fashioned racism. In closing, as always when conducting case studies, caution should be used when making generalizations beyond Mississippi.

\section{NOTES}

1. The Clarion Ledger is printed in Jackson, Mississippi.

2. The questions used to operationalize racial resentment have been well documented and will not be replicated here (for an in-depth review see, Sears, van Laar, Corrillo, \& Kosterman, 1997).

3. The survey was disseminated by the instructors of the various courses. Krysan, Schuman, Scott, and Beatty (1994) reveal that White respondents were more willing to express negative views on race-related issues when responding to mail questionnaires. We argue that the method adopted for the research at hand possesses the same strengths as described in the work of Krysan et al.

4. The universities and colleges surveyed for this analysis consist of six state-supported universities: the University of Mississippi, Mississippi State University, the University of Southern Mississippi, Jackson State University, Mississippi Valley State University, and Delta State University; and two private liberal arts colleges: Tougaloo College and Millsaps College.

5. Virtanen and Huddy (1998) report a Cronbach alpha of .53 for the oldfashioned racism variable.

6. Both the Racial Resentment and the Old-Fashioned Racism Scales were reduced to 0 to 1 bounds. We reversed two of the questions pertaining to racial resentment and two of the questions pertaining to old-fashioned racism to reflect the direction of our scale. In addition, opposition to Martin Luther King Jr. holiday (feeling thermometer)was employed to examine whether there was an anti-Black effect for both of these variables. The results indicate that Whites who were less likely to support MLK holiday also were more likely to express both of these racial attitudes.

7. In a poll conducted by The Clarion Ledger, $72 \%$ of Republicans support the old flag, compared with $38 \%$ Democrats and $56 \%$ of those who identified themselves as Independents (The Clarion Ledger, 2001).

8. Principal component factor analysis was employed to test the conceptual distinction between old-fashioned racism and racial resentment. The results confirm our argument that the questions tap two distinct concepts. 9. After employing generalized least squares (GLS) regression, the R2 is no longer bounded between 0 and 1, nor does it have any of the other properties that can be derived from the $\mathrm{R}^{2}$ when using ordinary least squares. In this analysis a weighted $R^{2}$ was produced where: $R^{2}=1-$ wsse / wsst, where wsst $=$ wssr + wsse, wsst is the weighted sum of squared deviations from the weighted mean, and wsse is the sum of squared transformed residuals.

\section{REFERENCES}

Bobo, L. (2000). Race and beliefs about affirmative action: Assessing the effects of interests, group threat, ideology, and racism. In D. O. Sears, J. Sidanius, \& L. Bob (Eds.), Racialized Politics (pp. 137-164). Chicago: The University of Chicago Press.

Brill, D. J., \& Grant, J. C. (1995, November 2-4). Symbols and the new South: The case of the Georgia state flag. Paper presented at the annual meeting of the Southern Political Science Association, Tampa, FL.

The Clarion Ledger. (2001). Retrieved from http://www.clarionledger.com/news/0102/08/q3.html. http://www.clarionledger.com/news/0102/08/q4.

Clark, J. A. (1997). Explaining elite attitudes on the Georgia flag. American Politics Quarterly, 25, 482-496.

Gilens, M. (1995). Racial attitudes and opposition to welfare. The Journal of Politics, 57, 994- 1014.

Howell, S. E. (1994). Racism, cynicism, economics, and David Duke. American Politics Quarterly, 22, 190-207.

Howell, S. E., \& Pelinka, A. (1994). Duke and Haider: Right wing politics in comparison. In G. Bischof \& A. Pelinka (Eds.), Contemporary Aus- 
trian studies Vol. 2: The Kreisky era in Austria. New Brunswick, NJ: Transaction.

Jackman, M. (1996). Individualism, self-interest, and White racism. Social Science Quarterly, 77, 760-767.

Jackman, M., \& Muha, M. J. (1984). Education and intergroup attitudes: Moral enlightenment, superficial democratic commitment, or ideological refinement? American Sociological Review, 49, 751-769.

Kinder, D. R., \& Sanders, L. M. (1996). Divided by color: Racial politics and democratic ideals. Chicago: University of Chicago Press.

Kinder, D., \& Sears, D. O. (1981). Prejudice and politics: Symbolic racism versus racial threats to the good Life. Journal of Personality and Social Psychology, 40, 414-431.

Knuckey, J., \& Orey, B. D. (2000). Symbolic racism in the 1995 Louisiana gubernatorial election. Social Science Quarterly, 81, 1027-1035.

Krysan, M., Schuman, H., Scott, L. J., \& Beatty, P. (1994,Fall). Response rates and response content in mail surveys versus face-to-face surveys. Public Opinion Quarterly, 58, 410-430.

Orey, B. D. (2001, Summer). A new racial threat in the new South? (A conditional) yes! American Review of Politics, 22, 233-255.

Reingold, B., \& Wike, R. S. (1998). Confederate symbols, southern identity, and racial attitudes: The case of the Georgia state flag. Social Science Quarterly, 79, 568-580.

Sears, D. O. (1988). Symbolic racism. In P. A. Katz \& D. A. Taylor (Eds.), Eliminating racism: Profiles in controversy (pp. 53-84). New York: Plenum.

Sears, D. O., \& Kinder, D. R. (1971). Racial tensions and voting in Los Angeles. In W. Z. Hirsch (Ed.), Los Angeles: Viability and prospects for metropolitan leadership. New York: Praeger.

Sears, D. O., van Laar, C., Corrillo, M., \& Kosterman, R. (1997). Is it really racism? The origins of White Americans' opposition to race-targeted policies. Public Opinion Quarterly, 61, 16-53.

Virtanen, S. V., \& Huddy, L. (1998). Old-fashioned racism and new forms of racial prejudice. The Journal of Politics, 69, 311-332.

Woliver, L. R., Ledford, A. D., \& Dolan, C. J. (2001). The South Carolina Confederate flag: The politics of race and citizenship. Politics $\mathcal{E}$ Policy, 29, 708-730.
Byron D'Andra Orey, Ph.D., currently serves as the 2003 Gallup Professor of Political Science at the University of Nebraska at Lincoln. His areas of interest include voting behavior, public opinion and institutions. 